\title{
Household Saving in Pakistan: Some Findings from Time-Series Data
}

\author{
ZIA M. QURESHI
}

The paper tests some household savings hypotheses with time-series data for Pakistan over the 1950-51-1976-77 period. The permanent income model is found to give a much better explanation of the year-to-year variations in household saving than does the simple current income model. Among other findings is a highly significant correlation between changes in the real rate of return on financial assets and household saving.

Very little quantitative work has been done in the past for the study of saving behaviour in Pakistan. A few studies that have attempted a quantification of some relevant behavioural relationships have, for the most part, been confined to estimating simple bivariate relationships between saving/consumption and income. ${ }^{1}$ A major reason for this appears to have been the lack of proper data on saving in the country. The savings estimates available thus far were too aggregative in character; having been derived residually from the national accounts, they supplied little or no information on the sectoral or asset-wise structure of aggregate savings.

In this paper an attempt has been made to test some household savings hypotheses, using the time-series data on savings in the household sector ${ }^{2}$ compiled in a recent study of saving in the country [26]. Total saving in the household sector has been derived in that study by adding up household savings in different types of financial and real assets. These data, which relate to Pakistan excluding former East Pakistan, cover the period 1950-51-1976-77. As such, they provide a consistent series which is long enough for a worthwhile analysis of household saving behaviour in the country.

The author is on the staff of the International Monetary Fund. He is indebted to Esra Bennathan, Keith Griffin, Eddie Jackson, David Soskice, an anonymous referee of this journal, and participants at a seminar given at Williams College, Williamstown, Mass., for comments on an earlier draft.

${ }^{1}$ The most notable among these is an early study by Ranis [27] of a sample of urban households in the city of Karachi.

${ }^{2}$ The term 'household sector' as used here includes unincorporated businesses. Given the type of data available, it is virtually impossible to separate the 'household' and 'business' components of the overall private non-corporate sector. 
The hypotheses tested in the paper comprise some formulations of the household savings-income relationship, as well as the relationship between household savings and financial market variables including the rate of interest and the rate of inflation. The object of the exercise is to go part of the way in filling the existing large gaps in quantitative research on the savings function in the country.

The paper is organized as follows. The relationship between saving and income is examined in Section I, with focus on the permanent income model. Section II presents regression results including the rate of growth of income as a separate argument in the savings function. Section III examines the possible effects of changes in interest rates and the rate of inflation on saving behaviour, and extends the regression analysis further by adding the two variables to the models used in the preceding sections. Finally, Section IV contains a summary discussion of the main findings of the paper.

\section{INCOME, SAVING AND THE PERMANENT INCOME MODEL}

Since the days of Keynes, income has been regarded as the chief determinant of saving. However, the exact nature of the savings-income relationship has remained a controversial subject. Most of the post-Keynesian developments in the theory of the savings/consumption function have revolved around three main theories, namely, Duesenberry's relative income hypothesis, Ando-ModiglianiBrumberg's life cycle hypothesis and Friedman's permanent income hypothesis. Although there are a number of differences, both of substance and of detail, between these theories, the following points may be deemed common to all three: (i) saving behaviour does not depend on current income alone but is also influenced by past income levels and by expectations about incomes in the future; (ii) in conditions of long-run steady-state growth, a rise in income will not in itself bring about a rise in the rate of saving; and (iii) short-term variations in income exercise an important influence on the short-term saving behaviour. As a corollary, the rate of growth of income is an important determinant of the rate of saving. ${ }^{3}$

Most of the empirical work that has been carried out on these theories with data from developing countries is related to the permanent income model. Very few studies have been concerned directly with empirical tests of the relative income hypothesis, while most of the work done on the life cycle theory has employed cross-section data. With the type of aggregate time-series data on household saving at our disposal, we restricted ourselves to testing some relatively simple formulations of the permanent income model.

${ }^{3}$ For a detailed exposition of these theories, see Duesenberry [8], Modigliani and Brumberg [25], Modigliani and Ando [24], and Friedman [10].
First, we used the following simple model:

$$
\mathrm{S}=\mathrm{a}+\mathrm{bY}_{\mathrm{P}}+\mathrm{cY}_{\mathrm{T}}
$$

where $\mathrm{Y}_{\mathrm{P}}$ is permanent income, or the expected part, and $\mathrm{Y}_{\mathrm{T}}$ is transitory income, or the unexpected part. Most tests of the permanent income model for developing countries have used this simple functional form. $\mathrm{Y}_{\mathrm{P}}$ is defined in terms of income expectations over a planning period and $\mathrm{Y}_{\mathrm{T}}$ is then estimated residually by deducting $Y_{P}$ from actual household disposable income $Y$. Several definitions of $Y_{P}$ have been used in the literature, with varying degrees of success. In most cases, however, the choice of a definition is to a large extent constrained by the availability of relevant data. In order to economise on degrees of freedom, most of the studies, especially time-series studies, have approximated $Y_{P}$ either by taking two- to three-year moving averages of actual income or by fitting simple time trends to the time-series data on income. ${ }^{4}$ Since the method of estimating $Y_{P}$ in this way is by nature somewhat arbitrary, many studies have employed more than one definition of $\mathrm{Y}_{\mathrm{P}}$.

In order to estimate the above formulation of the permanent income model, we tried two measures of permanent income, namely, (i) a simple average of the current year's and past two years' measured income, and (ii) income levels estimated from the relation $\operatorname{LnY}=a+b t$. In both cases, transitory income was defined as the difference between actual disposable income and the corresponding estimate of permanent income.

In addition, estimates were derived for the formulation of the permanent income model wherein permanent income is approximated by taking a weighted average of the current income and a series of past incomes, with the weights declining geometrically. For this purpose, the relationship that was estimated was $\mathrm{C}=\mathrm{a}+$ $\mathrm{bY}+\mathrm{cC}_{-1}$, which is derived from the geometric-lag model by means of the Koyck transformation. Estimates of the corresponding savings function were then obtained from the estimated consumption function by making use of the identity $\mathrm{C}+\mathrm{S}=\mathrm{Y}$.

Regression results for the above three formulations of the permanent income model are given in Table 1. ${ }^{5}$ The important thing to note in equations 1 (a) and 1(b)

${ }^{4}$ See, for example, Friend and Taubman [11], Williamson [35], Choudhury [5], and Gupta [14].

${ }^{5}$ Unless stated otherwise, the regressions have been carried out using the method of ordinary least squares and the statistical significance tests are at the 5-percent level. Figures in parentheses under the regression coefficients are t-ratios, and $\bar{R}^{2}$ and DW stand for coefficient of determination (adjusted for degrees of freedom) and Durbin Watson statistic respectively. The savings and income variables are gross of depreciation and are measured in real terms by deflating current fiscal-year values by the consumer price index with $1959-60=100$. Variables defined in absolute terms are in millions of rupees while the variables defined as ratios or rates are in percentages. 
is the relative size of the marginal propensities to save out of permanent and transitory incomes. According to Friedman's permanent income hypothesis, the whole of transitory income or the departure of actual income from expected income is saved, i.e. $\mathrm{MPS}_{\mathrm{T}}=1$. This is an extreme case which implies an extraordinarily heavy dependence of consumer spending on past experience. Although a majority of empirical studies of the permanent income model have shown that $\mathrm{MPS}_{\mathrm{T}}>\mathrm{MPS}_{\mathrm{P}}$, the hypothesis of unitary MPS $\mathrm{T}_{\mathrm{T}}$ has found little support. However, the question whether MPS ${ }_{\mathrm{T}}$ equals unity or not is not central to the argument here. We are interested primarily in testing the postulated excess of MPS $\mathrm{T}_{\mathrm{T}}$ over MPS $\mathrm{P}_{\mathrm{P}}$, and in approximating its magnitude for our set of data. Since the former is, ex hypothesi, much higher than the latter, the permanent income model implies that large and rapid increases in income along a growth path would result in a higher level of saving by causing larger divergences between expected and actual incomes.

\section{Table 1}

Permanent Income Model and Household Saving 1950-51-1976-77: Regression Results

\begin{tabular}{|c|c|c|c|c|c|c|c|c|c|c|}
\hline S & $=$ & $\begin{array}{r}-184.170 \\
(-0.693)\end{array}$ & + & $\begin{array}{l}0.084 Y_{P} \\
(6.047)\end{array}$ & & $\begin{array}{l}{ }^{*} \\
{ }_{(3.900)}\end{array}$ & $\begin{array}{l}\bar{R}^{2} \\
\mathrm{DW}\end{array}$ & $\begin{array}{l}= \\
=\end{array}$ & $\begin{array}{l}0.816 \\
2.095\end{array}$ & (1a) \\
\hline S & $=$ & $\begin{array}{r}-417.463 \\
(-1.358)\end{array}$ & + & $\begin{array}{l}0.111 \mathrm{Y}_{\mathrm{P}}^{+} \\
(8.378)\end{array}$ & + & $\begin{array}{l}0.117 \mathrm{Y}_{\mathrm{T}}^{+} \\
(1.190)\end{array}$ & $\begin{array}{l}\overline{\mathrm{R}}^{2} \\
\mathrm{DW}\end{array}$ & $\begin{array}{l}= \\
=\end{array}$ & $\begin{array}{l}0.752 \\
2.182\end{array}$ & (1b) \\
\hline S & $=$ & $\begin{array}{r}-124.509 \\
(-0.461)\end{array}$ & + & $\begin{array}{l}0.355 Y \\
(4.480)\end{array}$ & & $\begin{aligned} & 0.295 C_{-1} \\
&(-3.116)\end{aligned}$ & $\begin{array}{l}\bar{R}^{2} \\
\mathrm{DW}\end{array}$ & $\begin{array}{l}= \\
=\end{array}$ & $\begin{array}{l}0.818 \\
2.556\end{array}$ & (1c) \\
\hline$S$ & $=$ & $\begin{array}{c}5.271 \\
(0.222)\end{array}$ & + & $\begin{array}{c}0.477 \mathrm{Y} \\
(5.839)\end{array}$ & & $\begin{array}{l}{ }^{0.441 C_{-1}} \\
(-4.516)\end{array}$ & $\begin{array}{l}\overline{\mathrm{R}}^{2} \\
\mathrm{DW}\end{array}$ & $\begin{array}{l}= \\
=\end{array}$ & $\begin{array}{l}0.863 \\
1.876\end{array}$ & (1d) \\
\hline$S$ & $=$ & $\begin{array}{r}-113.659 \\
(-0.382)\end{array}$ & + & $\begin{array}{c}0.359 \mathrm{Y} \\
(3.886)\end{array}$ & & $\begin{aligned} & 0.298 C_{-1} \\
&(-2.725)\end{aligned}$ & $\begin{array}{l}\overline{\mathrm{R}}^{2} \\
\mathrm{DW}\end{array}$ & $\begin{array}{l}= \\
=\end{array}$ & $\begin{array}{l}0.720 \\
2.830\end{array}$ & (1e) \\
\hline S & $=$ & $\begin{array}{r}-123.435 \\
(-0.572)\end{array}$ & + & $\begin{array}{c}0.355 \mathrm{Y} \\
(4.628)\end{array}$ & & $\begin{array}{l}{ }^{0.294 C_{-1}} \\
(-3.226)\end{array}$ & $\begin{array}{l}\overline{\mathrm{R}}^{2} \\
\mathrm{DW}\end{array}$ & $\begin{array}{l}= \\
=\end{array}$ & $\begin{array}{l}0.823 \\
2.037\end{array}$ & (1f) \\
\hline
\end{tabular}

Note: $\mathrm{S}$ and $\mathrm{Y}$ are household saving and disposable income respectively while $\mathrm{Y}_{\mathrm{P}}, \mathrm{Y}_{\mathrm{T}}, \mathrm{Y}_{\mathrm{P}}^{+}$and $\mathrm{Y}_{\mathrm{T}}^{+}$are estimates of permanent and transitory income in the household sector according to definitions (i) and (ii) in the text respectively.
Our results show that when permanent income is defined as an average of current year's and last two years' measured income, the estimated MPS out of transitory income is much higher than that of permanent income, though much short of unity. Both the estimates are highly significant and there is a significant improvement in $\overline{\mathrm{R}}^{2}$ over that for the absolute income model. ${ }^{6}$ The results demonstrate that the distinction between permanent and transitory components of income exercises a significant influence on the consumption/saving decisions of households and that a high proportion of the latter is saved. They point to a quantitatively strong influence of rapid short-term increases in income on saving in the country.

However, when permanent income is estimated from the relation $\operatorname{LnY}=a+b t$, the difference between the two marginal propensities disappears almost completely the coefficient on $Y_{T}$ becomes insignificant and there is a significant fall in $\bar{R}^{2}$. The trend values yielded by the said relation appear to provide a much poorer approxima tion of expected incomes than do the simple three-year averages.

Four separate estimates were obtained for the Koyck distributed-lag formula tion of the permanent income model. Because of the presence of a lagged dependent variable among the explanatory variables and a compound error term subject to autocorrelation, estimation of this formulation by ordinary least squares (OLS) yields biased and inconsistent results. ${ }^{7}$ It was, therefore, necessary to cross-check the OLS results by comparing them with the results of the estimation of the same relation by some consistent estimation methods. Three such methods used were liviatan's lagged-value instrumental variable (IV) method, Wallis's extension of the IV method using a Cochrane-Orcutt transformation which approximates to generalised least squares (GLS), and another variant of the GLS method involving a transformation derived by Cooper of the Cochrane-Orcutt technique to correct for the asymptotic bias introduced into the estimates by the presence of a lagged dependent variable. ${ }^{8}$ Estimates yielded by these methods are given by equations 1(d) to 1(f) respectively; the corresponding OLS estimate is given by equation (1c).

Both variants of the GLS technique yield estimates of the coefficients that are very similar to the OLS estimates. The coefficients yielded by the IV technique are, however, somewhat different. The distributed-lag model does well in all the compu tations, and corroborates the results yielded by the formulation of the permanent income model given by equation (1a). The lag in the adjustment of household expenditure to changes in income is reflected in a substantial difference between the short- and long-run marginal propensities to save. The short-run MPS, given by the coefficient of $\mathrm{Y}$ in equations 2 (c) to $2(\mathrm{f})$, is shown to be about 0.35 by the OLS and GLS estimates and about 0.48 by the IV estimates. The corresponding estimates

${ }^{6}$ Compare equation (1a) with equation (2d) in Table 2.

${ }^{7}$ On this point see, for example, Johnston [18, Chap. 10].

${ }^{8}$ See N. Liviatan [21], Wallis [32], and Cooper [6]. 
of the long-run MPS are about 0.085 and 0.065 respectively. The long-run MPS is given by the expression $1-\left(\frac{b}{1-c}\right)$ in the original consumption function $\mathrm{C}=\mathrm{a}+\mathrm{bY}$ $+\mathrm{cC}_{-1}$ from which the estimates of the savings function given in equations $2(\mathrm{c})$ to 2 (f) have been derived.

The estimated coefficients of the distributed-lag model also provide some information about the average length of the planning horizon of the expenditure units. If this horizon were infinite, each term in the expression measuring permanent income would receive equal weight. The particular weighting scheme employed by the model posits that expenditure decisions are influenced more by present than by past income. The estimated coefficients of the consumption function showed that the influence of past income levels on current expenditure became very small after two to three years. Put differently, an overwhelmingly large part (over 95 percent) of the full, long-run adjustment of consumption expenditure to a sustained increase in current income was indicated to take place within the following two to three years. This suggests that a definition of permanent income in terms of income expectations generated by levels of income experienced during the past few years, such as a three-year period used by us, provides a fairly reasonable approximation of the true magnitudes in the present case. ${ }^{9} \quad$ The explanatory power (as indicated by $\overline{\mathrm{R}}^{2}$ ) of the distributed-lag model appears to be roughly similar to that of the model using a three-year average of the most recent levels of income as a measure of permanent income.

\section{RATE OF GROWTH OF INCOME AND SAVING}

As noted above, an implication common to the post-Keynesian theories of the savings function is that the rate of growth of income is a major determinant of saving. ${ }^{10}$ Within the framework of these theories, this influence derives largely from lags in the adjustment of consumption to rapid increases in income; large and rapid increases in income tend to raise the rate of saving by raising transitory income relative to permanent income, or current income relative to previous peak income. However, the positive impact of a rise in the rate of growth may not be limited to this line of causation alone. A higher rate of growth may also stimulate saving through what McKinnon has termed the 'portfolio-effect' of growth. This effect comes about as the public tries to maintain its desired ratio of money balances and other financial assets to income by saving more. ${ }^{11}$ Further, a high growth momentum helps create an environment of increasing prosperity and a general

${ }^{9}$ Several empirical studies of the savings function in developing countries have yielded similar results; see, for example, the studies listed in footnote 4.

${ }^{10}$ For a discussion of the similarity of these theories on this point, see Swamy [30], Houthakker and Taylor [17], and Singh [28].

${ }^{11}$ See McKinnon [22, pp. 123-9]. forward movement in the economy, which may be highly conducive to entrepreneur ial saving. Finally, given the initially very low average levels of living in developing countries, a slow or gradual increase in income may have only a limited effect on the average savings ratio whereas a rapid increase may have a fairly substantial effect.

The results presented in the previous section for the permanent income model indicated support for the hypothesis that rapid increases in income tended to raise the rate of saving. A number of studies of the savings function in developing countries have included the rate of growth of income explicitly in the function as an independent regressor, and most of the empirical tests have produced significant and positive coefficients for this variable. ${ }^{12}$ Table 2 gives the results of some relatively simple models including an income growth variable and using our set of data. ${ }^{13}$

The results show that the addition of this variable to the simple savings-income model brings about an appreciable improvement in the estimated relationship. This is particularly true when the savings ratio is used as the dependent variable. Comparing equations 2(b) and 2(c) with equations 2(e) and 2(f) we see that the inclusion of the rate of growth of income in the model more than doubles its explanatory power. Equation 2(a) shows that an increase in the growth rate by one percentage point raises savings by about 2.5 percent (measured at the mean) Equations 2(b) and 2(c) indicate that the same increase in the growth rate raises the savings ratio by about one-quarter of a percentage point.

The above results relate to the overall period 1950-51-1976-77. The relationship between savings and income growth turned out to be significantly stronger when the same functions were estimated for the period 1959-60-1976-77, thereby leaving out the 1950 s which was a period of a relatively slow growth in the economy (real income fell in some years during this period). This is shown by equations $2(\mathrm{~g})$ to 2(i). Equation $2(\mathrm{~g})$ shows that an increase in the growth rate by one percentage point is now associated with an increase in savings of more than 4.5 percent (measured at the mean). Equations 2(h) and 2(i) show that the associated increase in the savings ratio is a little less than one-half of a percentage point.

The results thus indicate that the rate of income growth has been an important determinant of the propensity to save in the country, and that its influence was

${ }^{12}$ See, for example, Houthakker [16], Swamy [30], Williamson [34], Singh [28], and Leff and Sato [20].

${ }^{13} \mathrm{~A}$ valid question about these single-equation results is the simultaneity problem, i.e. the problem of the feed-back effect of the dependent variable on the rate of growth. Strictly speaking, the savings function cannot be estimated without setting up a whole system of simultaneous equations which take into account all such feed-back effects. Unfortunately, we are prevented from undertaking any such exercise because econometric research into othe structural relationships in the economy, e.g. the aggregate production function, that are required for this purpose has also been seriously lacking. For the present, therefore, the single-equation models being used here are perhaps the best that may be attempted. 
Table 2

Rate of Growth of Income and Household Saving 1950-51-1976-77: Regression Results

\begin{tabular}{|c|c|c|c|c|c|c|c|}
\hline$S=$ & $\begin{array}{r}-508.703 \\
(-2.008)\end{array}$ & $\begin{array}{r}0.106 \mathrm{Y} \\
(9.744)\end{array}$ & $\begin{array}{r}+48.375(\Delta \mathrm{Y}) \\
(2.870)^{(\mathrm{Y})}\end{array}$ & $\begin{array}{l}\bar{R}^{2} \\
\text { DW }\end{array}$ & $\begin{array}{l}= \\
=\end{array}$ & $\begin{array}{l}0.815 \\
2.054\end{array}$ & $(2 a)$ \\
\hline$\frac{\mathrm{S}}{\mathrm{Y}}=$ & $\begin{array}{c}3.881 \\
(1.7201)\end{array}$ & $\begin{array}{c}0.0099 \mathrm{Y}^{*} \\
(1.781)\end{array}$ & $+\quad \frac{0.222(\Delta \mathrm{Y})}{(3.202)^{(\mathrm{Y})}}$ & $\begin{array}{l}\bar{R}^{2} \\
\text { DW }\end{array}$ & $\begin{array}{l}= \\
=\end{array}$ & $\begin{array}{l}0.377 \\
1.450\end{array}$ & $(2 b)$ \\
\hline$\frac{S}{Y}=$ & $\begin{array}{l}-17.024 \\
(-1.243)\end{array}$ & $\begin{array}{c}4.163 \operatorname{LnY} Y^{*} \\
(1.815)\end{array}$ & $+\quad \underset{(3.142)(\mathrm{Y})}{0.219(\Delta \mathrm{Y})}$ & $\begin{array}{l}\bar{R}^{2} \\
\text { DW }\end{array}$ & $\begin{array}{l}= \\
=\end{array}$ & $\begin{array}{l}0.379 \\
1.467\end{array}$ & $(2 c)$ \\
\hline $\mathrm{S}=$ & $\begin{array}{r}-423.075 \\
(-1.481)\end{array}$ & $\begin{array}{c}0.112 \mathrm{Y} \\
(9.176)\end{array}$ & & $\begin{array}{l}\overline{\mathrm{R}}^{2} \\
\mathrm{DW}\end{array}$ & $\begin{array}{l}= \\
=\end{array}$ & $\begin{array}{l}0.762 \\
2.197\end{array}$ & $(2 d)$ \\
\hline$\frac{\mathrm{S}}{\mathrm{Y}}=$ & $\begin{array}{c}2.888 \\
(1.104)\end{array}$ & $\begin{array}{c}0.014 \mathrm{Y}^{*} \\
(2.331)\end{array}$ & & $\begin{array}{l}\overline{\mathrm{R}}^{2} \\
\mathrm{DW}\end{array}$ & $\begin{array}{l}= \\
=\end{array}$ & $\begin{array}{l}0.146 \\
1.600\end{array}$ & $(2 \mathrm{e})$ \\
\hline$\frac{\mathrm{S}}{\mathrm{Y}}=$ & $\begin{array}{l}-28.464 \\
(-1.852)\end{array}$ & $\begin{array}{c}6.225 \mathrm{LnY}^{*} \\
(2.433)\end{array}$ & & $\begin{array}{l}\bar{R}^{2} \\
\text { DW }\end{array}$ & $\begin{array}{l}= \\
=\end{array}$ & $\begin{array}{l}0.159 \\
1.625\end{array}$ & $(2 f)$ \\
\hline \multicolumn{8}{|c|}{$1959-60-1976-77$} \\
\hline $\mathrm{S}=$ & $\begin{array}{r}-498.217 \\
(-1.174)\end{array}$ & $\begin{array}{c}0.094 \mathrm{Y} \\
(6.370)\end{array}$ & $\begin{array}{r}+118.626(\Delta \mathrm{Y}) \\
(4.088)(\mathrm{Y})\end{array}$ & $\begin{array}{l}\bar{R}^{2} \\
\text { DW }\end{array}$ & $\begin{array}{l}= \\
=\end{array}$ & $\begin{array}{l}0.766 \\
2.181\end{array}$ & $(2 \mathrm{~g})$ \\
\hline$\frac{\mathrm{S}}{\mathrm{Y}}=$ & $\begin{array}{c}8.348 \\
(2.579)\end{array}$ & $\begin{array}{c}-0.0016 \mathrm{Y}^{*} \\
(-0.214)\end{array}$ & $+\quad \begin{array}{c}0.430(\Delta \mathrm{Y}) \\
(3.867)^{(\mathrm{Y})}\end{array}$ & $\begin{array}{l}\overline{\mathrm{R}}^{2} \\
\mathrm{DW}\end{array}$ & $\begin{array}{l}= \\
=\end{array}$ & $\begin{array}{l}0.433 \\
2.004\end{array}$ & $(2 \mathrm{~h})$ \\
\hline$\frac{S}{Y}=$ & $\begin{array}{l}11.295 \\
(0.591)\end{array}$ & $\begin{array}{c}-\quad 0.598 \operatorname{LnY} Y^{*} \\
(-0.190)\end{array}$ & 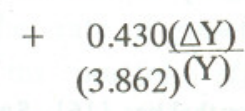 & $\begin{array}{l}\bar{R}^{2} \\
\mathrm{DW}\end{array}$ & $\begin{array}{l}= \\
=\end{array}$ & $\begin{array}{l}0.433 \\
2.004\end{array}$ & $(2 \mathrm{i})$ \\
\hline
\end{tabular}

Note: $\mathrm{Y}^{*}$ is per capita household disposable income and $\frac{\Delta \mathrm{Y}}{\mathrm{Y}}=100.0\left(\mathrm{Y}-\mathrm{Y}_{-1}\right) / \mathrm{Y}_{-1}$ comparatively much stronger for the period after the 1950s (especially over the 1960 s when growth rates were at their peak). ${ }^{14}$

\section{INTEREST RATES, INFLATION AND SAVING}

Economic theory does not provide an unequivocal a priori expectation regarding the direction of the relationship between interest rates and saving. The indeterminacy in the theory stems largely from the opposite influences that the income and substitution effects of an interest rate change exercise on the propensity to save, with the net result depending on their relative strength which can be determined only empirically. The income effect tends to raise consumption out of present income as it enables consumers to maintain the same amount of consumption in the future as before but with less saving today. The substitution effect, on the other hand, tends to reduce present consumption by making it more expensive in terms of the future consumption that is forgone as a result.

Then, it is argued by some that whereas an increase in interest rates may lead to an increase in saving in interest-bearing financial assets (as it is a reward for saving in this particular form), it may not bring about an increase in total saving (and may even reduce it) by depressing saving in the form of direct investment in physical capital assets whose relative profitability is consequently lowered. Thus, according to this line of argument, interest rates may be more significant in determining investment portfolios or the channels into which savings flow than in altering saving propensities.

In a more recent work in this area in developing countries, an alternative view has been proposed that stresses a relationship of complementarity between private saving in financial assets and investment in physical capital goods and singles out the real rate of interest as an important variable influencing both. For a large majority of investors in these countries, according to this view which is frequently referred to as the McKinnon complementarity hypothesis, ${ }^{15}$ saving in the form of accumulation of financial assets (chiefly currency balances and deposits) acts as a 'conduit' through which the accumulation of physical capital assets takes place. This is because, given the relatively under-developed financial structures in these countries and the consequent limited flow of external finance, investment plans of household entrepreneurs and small unincorporated business units (which dominate the productive

${ }^{14}$ That the influence of income growth on savings was much stronger after the 1950 s was also indicated by the estimates of the relevant functions for the sub-period 1950-51-1958-59 (not shown here). For instance, estimation of equation $2 \mathrm{~g}$ for this period showed that the coefficient of the income-growth variable was significantly smaller than that for the period 1959-601976-77 and that it was statistically significant only at the 10 percent level. Application of the Chow F-test also showed that the same relationship gave significantly different results for the two sub-periods.

${ }^{15}$ See McKinnon [22, esp. Chap. 6]. 
activity in these countries but get a disproportionately small share in the total availability of external finance) are to a large extent subject to the constraint of selffinance. In order to be able to invest in relatively lumpy capital goods, investors in these categories must save and accumulate sufficiently large financial balances over a period of time. An increase in the rate of interest under these conditions, according to this view, will stimulate both financial savings and real investment: financial savings will be stimulated because the rate of return thereon increases; the incentive to invest will be stimulated because the opportunity cost of accumulating financial balances with a view to eventually investing them in physical capital falls, thereby enlarging the financial conduit. Further, an increase in the rate of interest may also induce larger savings by increasing the need for internal financing in the case of entrepreneurs who previously had access to cheap external finance.

Given the diversity of the possible effects of a change in interest rates on saving, it is not surprising to find that empirical studies of the savings-interest rate relationship have produced a variety of results. The findings have ranged from significantly positive coefficients on the rate of interest to significantly negative ones. ${ }^{16}$ However, the empirical work relating to developing countries in recent years has produced more consistent results, with a majority of the studies reporting a positive (in some cases quantitatively strong) correlation between saving and changes in interest rates. ${ }^{17}$

In the case of inflation also, a priori reasoning does not provide a unique answer to the question whether it promotes or discourages saving. A number of channels of influence between the two have been pointed out and elaborated in the literature. The case for inflationary finance is built largely on the premise that inflation tends to redistribute income in favour of groups and institutions in the economy with higher propensities to save. Within the private sector, income is redistributed from wage- and salary-earners to entrepreneurs (because of a lag in the adjustment of wages and salaries to a rising price level) and from creditors/rentiers to debtors (as contracts are generally fixed in nominal terms), thereby placing more resources directly in the hands of investors who are supposed to have higher saving propensities. Thus higher investment, financed through monetary expansion at full capacity, will generate its own savings as the ensuing inflation directs resources from relatively low savers in the economy to relatively high savers. This is the so-called Keynesian approach to inflationary finance. Further, inflation, being a tax on holding money, also transfers resources from the public to the government (monetary authorities or issuers of money). A larger proportion of the resources thus made available to the government, it is assumed, is channelled into investment

${ }^{16}$ For examples of the former type of results, see C. Wright [36;37], and Gupta [14]. For examples of the latter type of results, see Williamson [35], and Weber [33].

${ }^{17}$ See, for example, Brown [4], Abe, Fry et al. [2], and Fry [12]. projects than would have been saved/invested if these resources had been left with the private sector, thus raising the overall rate of saving in the economy. This is the so-called quantity theory approach to inflationary finance. ${ }^{18}$

The two types of income-redistribution effects are not mutually exclusive, of course, and an excess-demand inflation is likely to involve both. The effects of inflation on saving, however, are not limited to those emanating from the redistribution of income alone. Inflation may increase saving through the so-called realbalance effect as reflected in the attempts of the holders of money balances and other financial assets to restore the real value of their holdings after an increase in prices.

But this is only one side of the picture. Inflation can also be detrimental to savings in several ways. First, the processes outlined above, whereby inflation might exert a favourable influence on the propensity to save, have some important qualifications. For example, the redistributive effects of inflation noted above are normally associated only with a particular type of inflation, namely excess-demand inflation. Further, even when inflation is of a pure excess-demand variety, there is still no guarantee that the redistribution of income from wage-earners to entrepreneurs will take place as this process may be thwarted by a wage-price spiral where wages quickly catch up with price increases. ${ }^{19}$

Secondly, it is not clear whether the net effect on saving of income redistribution through inflation would be positive or negative. Whereas the redistribution of income from wages in favour of entrepreneurial incomes may be expected to raise the propensity to save, no such generalisation can be made in the case of the redistribution of income from the private to public sector, and the question has to be decided largely on empirical grounds.

Thirdly, in so far as a disproportionately large chunk of loanable funds in the economy is monopolised by a relatively small minority of establishments in big business, inflation may have a detrimental effect on the overall propensity to save by penalising a large proportion of savers in the population, who are the source of these funds, for the benefit of a handful of vested interests.

Fourthly, the revenue accruing to monetary authorities from the inflation tax will tend to decline as the tax becomes increasingly burdensome with a rising rate of inflation and the public responds by cutting down its holdings of money balances, thus narrowing the base on which the tax operates. This results in reducing the amounts that the public would otherwise have saved voluntarily in the form of real cash balances.

${ }^{18}$ Under a progressive income-tax structure, inflation would also transfer resources to the government through higher tax yields at an unchanged level of real income.

${ }^{19}$ However, the bulk of empirical evidence shows that the wage-price coefficient has typically been less than unity in the past, even in the long run. This is particularly true in the case of developing countries where trade union activity is generally weak in strength and limited in scope. 
Finally, a rising price level discourages voluntary saving not only in the form of cash balances but also in the form of various other types of financial assets by reducing the expected real rate of return on those assets. This has further serious implications for savings if financial savings are considered to be complementary with physical investments, as they are in the McKinnon model.

It is clear from the above that the net effect of inflation on saving can be either positive or negative, depending on the particulars of the case in question. This is one major reason why empirical work on the subject has in several cases yielded inconclusive results, though in a majority of studies the relationship between saving and inflation has been found to be negative. The inconclusive nature of the results is particularly characteristic of studies that have used cross-country data. Given the variety of conditions in different countries associated with any given rate of inflation, conditions that have an important bearing on the relationship being tested, it is not surprising that most of these studies have yielded rather poor results. This becomes evident when we consider that the same rate of inflation can be associated with different types of inflation in different countries, with different supply responses, with different speeds of adjustment to inflation, etc., etc. This is also reflected in the fact that studies that have used time-series data on individual countries have generally reported much better results. ${ }^{20}$

Against this background, we now examine the results yielded by our set of data. To determine the role of interest rate changes on saving in the household sector, we added an interest rate variable to the savings-income models considered in the preceding sections. Table 3 gives the results.

The rate of interest used in the regressions for the overall period 1950-511976-77 was the average annual (quarterly average) rate of interest on scheduled banks' six months to one year time deposits, converted into real terms by subtracting from it the corresponding annual rate of change in the consumer price index. ${ }^{21}$ This interest rate series was preferred on a priori grounds to other series available for the whole of this period, namely the call money rate, the yield on long-term government bonds and the average interest rate on scheduled banks' savings deposits. Time deposits constitute a substantial proportion of the total household saving in financial assets in the country and their rate of return can, therefore, approximate the average return on the various types of financial assets to savers in the sector better than the other rates mentioned above possibly can. A weighted average rate of interest on all types of interest-bearing deposits could have provided a still better proxy but such a series was available only for the period 1959-60 onwards. However, the estimation

${ }^{20}$ For examples of studies using cross-country data, see Williamson [34], Thirlwall [31], and Abe, Fry et al. [2]. For examples of studies using time-series data on individual countries, see Diwan [7], Gupta [13,15], and Brown [4].

${ }^{21}$ Using the actual rate of inflation as a proxy for the expected rate of inflation. See Akhtar [3] on the reasonableness of this procedure in the case of Pakistan. of the same equations with this interest rate made very little difference to the results, as can be seen from equations $3(e)$ to $3(j)$ in the table.

Table 3

Rate of Interest and Household Saving 1950-51-1976-77: Regression Results

\begin{tabular}{|c|c|c|c|c|c|}
\hline $\mathrm{S}$ & $\begin{array}{r}=-602.170+0.124 \mathrm{Y} \\
(-2.394)(11.130)\end{array}$ & $\begin{array}{r}+41.543 \mathrm{r} \\
(3.161)\end{array}$ & $\begin{array}{l}\overline{\mathrm{R}}^{2}= \\
\mathrm{DW}=\end{array}$ & $\begin{array}{l}0.825 \\
2.124\end{array}$ & (3a) \\
\hline $\mathrm{S}$ & $\begin{array}{c}=-349.843+0.0996 \mathrm{Y}_{\mathrm{P}} \\
(-1.501) \quad(7.733)\end{array}$ & $+\underset{(3.772)}{0.432 \mathrm{Y}_{\mathrm{T}}}+\begin{array}{l}37.504 \mathrm{r} \\
(3.097)\end{array}$ & $\begin{array}{l}\overline{\mathrm{R}}^{2}= \\
\mathrm{DW}=\end{array}$ & $\begin{array}{l}0.866 \\
2.126\end{array}$ & $(3 b)$ \\
\hline $\mathrm{S}$ & $\begin{aligned}=- & 603.154+0.117 \mathrm{Y} \\
& (-2.480)(10.080)\end{aligned}$ & $\begin{array}{r}+29.806 \Delta \frac{\Delta Y}{Y}+\begin{array}{r}29.533 r \\
(1.621)\end{array} \quad(2.007)\end{array}$ & $\begin{array}{l}\overline{\mathrm{R}}^{2}= \\
\mathrm{DW}=\end{array}$ & $\begin{array}{l}0.836 \\
2.116\end{array}$ & $(3 c)$ \\
\hline & $\begin{array}{r}=-742.460+0.075 Y \\
(-3.021) \quad(6.884)\end{array}$ & $\begin{array}{r}+28.785 \mathrm{r} \\
(2.241)\end{array}$ & $\begin{array}{l}\overline{\mathrm{R}}^{2}= \\
\mathrm{DW}=\end{array}$ & $\begin{array}{l}0.636 \\
2.308\end{array}$ & $(3 \mathrm{~d})$ \\
\hline & & $1959-60-1976-77$ & & & \\
\hline $\mathrm{S}$ & $\begin{array}{c}=-289.363+0.116 \mathrm{Y} \\
(-0.614) \quad(6.364)\end{array}$ & $\begin{array}{r}+54.118 \mathrm{r} \\
(3.072)\end{array}$ & $\begin{array}{l}\overline{\mathrm{R}}^{2}= \\
\mathrm{DW}=\end{array}$ & $\begin{array}{l}0.697 \\
2.128\end{array}$ & $(3 e)$ \\
\hline $\mathrm{S}$ & $\begin{array}{c}=-305.192+0.092 Y_{P} \\
(-0.808) \quad(5.619)\end{array}$ & $+\underset{(3.784)}{0.592 \mathrm{Y}_{\mathrm{T}}}+\begin{array}{r}47.773 \mathrm{r} \\
(3.348)\end{array}$ & $\begin{array}{l}\overline{\mathrm{R}}^{2}= \\
\mathrm{DW}=\end{array}$ & $\begin{array}{l}0.805 \\
2.050\end{array}$ & (3f) \\
\hline$S$ & $\begin{array}{c}=-630.673+0.108 Y \\
(-1.703) \quad(7.907)\end{array}$ & 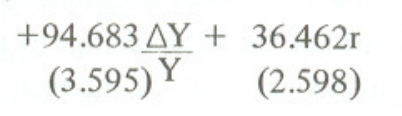 & $\begin{array}{l}\overline{\mathrm{R}}^{2}= \\
\mathrm{DW}=\end{array}$ & $\begin{array}{l}0.831 \\
2.268\end{array}$ & $(3 g)$ \\
\hline $\mathrm{S}$ & $\begin{array}{c}=-333.284+0.118 \mathrm{Y} \\
(-0.698)(6.360)\end{array}$ & $\begin{array}{r}+53.146 \mathrm{r}^{*} \\
(3.043)\end{array}$ & $\begin{array}{l}\overline{\mathrm{R}}^{2}= \\
\mathrm{DW}=\end{array}$ & $\begin{array}{l}0.695 \\
2.121\end{array}$ & (3h) \\
\hline $\mathrm{S}$ & $\begin{array}{c}=-336.872+0.095 \mathrm{Y}_{\mathrm{P}} \\
(-0.867) \quad(5.523)\end{array}$ & $\begin{array}{c}0.585 \mathrm{Y}_{\mathrm{T}} \\
(3.661)\end{array}$ & $\begin{array}{l}\overline{\mathrm{R}}^{2}= \\
\mathrm{DW}=\end{array}$ & $\begin{array}{l}0.797 \\
2.027\end{array}$ & (3i) \\
\hline S & $\begin{array}{c}=-654.593+0.110 Y \\
(-1.765)(7.742)\end{array}$ & $\begin{array}{r}+94.496 \Delta \mathrm{Y}+35.196 \mathrm{r}^{*} \\
(3.527) \mathrm{Y}\end{array}$ & $\begin{array}{l}\overline{\mathrm{R}}^{2}= \\
\mathrm{DW}=\end{array}$ & $\begin{array}{l}0.827 \\
2.234\end{array}$ & $(3 \mathrm{j})$ \\
\hline & 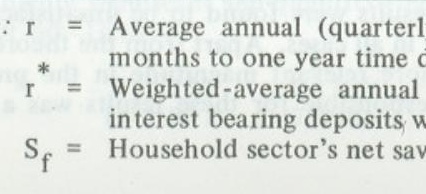 & $\begin{array}{l}1 \text { (quarterly average) real rate } \\
\text { with scheduled banks (\%). } \\
\text { aving in financial assets. }\end{array}$ & 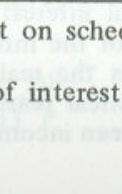 & 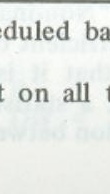 & \\
\hline
\end{tabular}


It will be seen that the coefficient of the real ${ }^{22}$ rate of interest is positive and statistically significant in all the regressions reported in Table 3 . The size of the coefficient shows that in quantitative terms as well the relationship between this variable and saving is fairly strong. Thus equation 3(a) to 3(c) show that an increase (decrease) in the real rate of interest by one percentage point tended to raise (reduce) total household saving by 1.5 percent to over 2 percent (measured at the mean). This indicates a strong response on the part of savers to changes in the real rate of return on commonly held financial assets such as bank deposits.

It will be noticed that the rate of growth of income becomes insignificant at conventional levels of significance with the inclusion of the interest rate variable in the savings function for the overall period 1950-51-1976-77 (equation 3c). But, as we saw earlier, the relationship between saving and income growth appears much stronger if the early 1950s are left out of the estimation. Thus we see that in equations $3(\mathrm{~g})$ and $3(\mathrm{j})$, the coefficients of both the rate of growth of income and the rate of interest are significant at the 5 percent level, and are strongly positive.

To carry the above findings a little further by attempting an identification of the transmission mechanism through which changes in interest rates influence saving, we estimated equation 3a with the household sector's saving in financial assets substituted for the sector's total saving as the dependent variable. The result is shown by equation 3d. According to this result, an increase (decrease) in the real rate of interest by one percentage point tended to raise (reduce) net household saving in financial assets by about 3.5 percent. In proportional terms, the effect is much larger than that seen above in the case of total household saving. This is what one would normally expect as the real rate of interest is primarily a measure of the real rate of return on financial assets. But the more interesting point to note is that the change in household saving in financial assets accounts for, in absolute terms, only a part (though a predominant one) of the total change in the sector's saving that takes place as a result of a change in the real rate of interest. A significantly large part of the total is accounted for by a change in the same direction in the sector's saving in the form of direct investment in real assets. Comparing equations 3(a) with 3(d), our estimates show that the latter type of saving accounts for, on average, about 20 percent of the total change.

In the light of our earlier discussion of the possible effects of interest rate changes on saving behaviour, the following inference about the transmission mechanism may be drawn from the above findings. The positive effect of an increase in the real rate of interest in the economy works primarily on saving in financial

${ }^{22}$ Nominal interest rates were also tried but the results were found to be unsatisfactory. The coefficient of the interest rate term was insignificant in all cases. Apart from the theoretica reason that it is the real rate of interest that is the more relevant magnitude in the presen context, a statistical reason that seemed to be partly responsible for these results was a high correlation between income and nominal interest rates. assets by raising the real rate of return on such assets. This in turn induces a further increase in saving by increasing the incentives to invest in physical capital assets. Our findings thus lend support to what was referred to above as the McKinnon complementarity hypothesis. ${ }^{23}$

The policy followed in Pakistan has been one of low interest rates. The nominal rates of interest on bank deposits in the country were in the past determined by a combination of mutual agreements between the leading scheduled banks and directives from the State Bank of Pakistan. The line of policy pursued was to keep the rates at low levels, adjusting them upward with time in small discrete steps. The rate of inflation, on the other hand, underwent a good deal of fluctuation. Although these fluctuations took place within a low to moderate range of values up to the early 1970s, the low level of nominal interest rates meant that the real return on bank deposits became negative whenever the rate of inflation registered even a moderate increase. Seen in the light of the fact that the real rate of interest in the country generally remained at low - often negative - levels, the strong correlation between changes in real interest rates and the level of household saving indicated by our regression results appears all the more remarkable. It points to a potentially even stronger response on the part of savers in the sector to sizable increases in the real rate of return on commonly held financial assets such as bank deposits. It also shows that by keeping the real return on such assets depressed, the low interest rate policy followed in the country had the effect of keeping household financial savings much below the level that would have been forthcoming under a more favourable interest rate regime.

When the rate of inflation was introduced directly into the savings models, its coefficient was found to be consistently negative and highly significant, as the regression estimates given in Table 4 indicate. ${ }^{24}$ The impact of inflation on household saving is shown to have been negative on balance. The values of the coefficients show that a rise in the rate of inflation by one percentage point tended to reduce savings by about 1.5 percent to over 2 percent (measured at the mean). This points to a remarkable similarity between the estimated coefficients of the real rate of interest and the rate of inflation. Comparing equations 3(a) to 3(c) with

${ }^{23}$ Supporting evidence for the McKinnon complementarity hypothesis has also been reported by another study relating to Pakistan. Estimating some demand for money functions with data relating to pre-1971 Pakistan (i.e. including former East Pakistan), Abe, Fry et al. found that the accumulation of money balances was positively and significantly correlated with the overall level of saving in the economy [1].

${ }^{24}$ The growth rate variable appears insignificant (at conventional levels) in equation $4 \mathrm{c}$. However, we have seen that this variable gives much better results if we leave out the 1950 s over which the rate of income growth was generally low. Thus both this variable and the new variable are highly significant and quantitatively strong in the following equation estimated for the period 1959-60-1976-77.

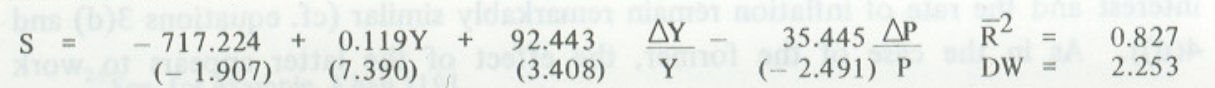


equations 4(a) to 4(c), we see that the two sets of coefficients are very similar. This is not a surprising result considering that changes in the real rate of interest in the country were to a large extent determined by changes in the rate of inflation. This was so because, as we noted above, the policy-determined nominal interest rates were allowed to increase only gradually in small discrete steps while the rate of inflation fluctuated a good deal. Another inference that can be drawn from this result is that a large part of the adverse effect of inflation on saving was transmitted through its effect of lowering the real rate of return on financial assets. These assets account for a substantial proportion of total household saving and their importance has been increasing with time. Further, in so far as the accumulation of financial assets serves as a conduit for real capital accumulation, the adverse effect may not remain confined to the former alone. Thus it seems that by depressing the real return available to investors on various types of financial assets, and by increasing the opportunity cost of accumulating cash balances for future real investment, inflation had a strong unfavourable effect on household saving which substantially outweighed any possible favourable effects that it may also have generated.

Table 4

Inflation and Household Saving

1950-51-1976-77: Regression Results

\begin{tabular}{|c|c|c|c|}
\hline $\begin{array}{r}S=-697.143+0.136 Y \\
(-2.724)(10.750)\end{array}$ & $\begin{array}{l}-42.078 \underline{\Delta P} \\
(-2.292)\end{array}$ & $\begin{array}{l}\overline{\mathrm{R}}^{2}=0.829 \\
\mathrm{DW}=2.148\end{array}$ & $(4 a)$ \\
\hline $\begin{array}{c}S=-438.796+0.111 Y_{P} \\
(-1.812)(7.512)\end{array}$ & $+\underset{(3.680)}{0.425 \mathrm{Y}_{\mathrm{T}}-{ }_{(-3.069)}^{37.185 \Delta \mathrm{P}}}$ & $\begin{array}{l}\bar{R}^{2}=0.866 \\
D W=2.146\end{array}$ & $(4 b)$ \\
\hline $\begin{array}{r}S=-670.728+0.126 Y \\
(-2.682)(9.031)\end{array}$ & $\begin{array}{r}+27.969 \frac{\Delta \mathrm{Y}}{}-30.422 \frac{\Delta \mathrm{P}}{\mathrm{P}} \\
\quad(1.502) \mathrm{Y}_{(-2.072)}\end{array}$ & $\begin{array}{l}\bar{R}^{2}=0.838 \\
\mathrm{DW}=2.133\end{array}$ & $(4 c)$ \\
\hline $\begin{array}{c}\mathrm{S}_{\mathrm{f}}=-800.804+0.082 \mathrm{Y} \\
(-3.154)(6.584)\end{array}$ & $\begin{array}{l}-28.010 \frac{\Delta P}{P} \\
(-2.209)^{P}\end{array}$ & $\begin{array}{l}\overline{\mathrm{R}}^{2}=0.634 \\
\mathrm{DW}=2.293\end{array}$ & (4d) \\
\hline
\end{tabular}

Note: $\frac{\Delta \mathrm{P}}{\mathrm{P}}=100.0\left(\mathrm{P}-\mathrm{P}_{-1}\right) / \mathrm{P}_{-1}, \mathrm{P}$ being the consumer price index.

The same point emerges more clearly when as in the case of the interest rate variable, the savings function is estimated with household saving in financial assets as the dependent variable in place of total household saving. The regression estimate is given by equation 4(d). The absolute values of the coefficients of the real rate of interest and the rate of inflation remain remarkably similar (cf. equations $3(\mathrm{~d})$ and 4(d)). As in the case of the former, the effect of the latter appears to work primarily through saving in financial assets, though the direction of the effect is now, of course, reversed. The depressing effect on saving in financial assets is accompanied by a similar, though quantitatively smaller, effect on saving in the form of direct investment in real assets.

A point that may be raised here is that at the rates of inflation that prevailed in the country for most of the time during the period under consideration, inflation was never really. employed as a strategy for promoting saving and growth. Now it is true that excluding the 1970 s, the rate of inflation in the country only once exceeded 10 percent per annum. In most other years it hovered around 5-6 percent per annum. But the important consideration to note is that it is not only the absolute level of the rate of inflation that is relevant from the point of view of the strategy in question; this rate has to be seen in relation to the other relevant variables and conditions in the economy which have a determining influence on the mechanics of this strategy. The strategy of inflationary financing of development sets much store by the redistributive effects of inflation in favour of the entrepreneurial classes to realise its growth and savings objectives. Whether inflation succeeds in redistribut ing resources to the favoured groups or not depends not only on the absolute rate of inflation but also, inter alia, on such factors as what happens to money wages (for redistribution from workers) and the level of interest rates (for redistribution from creditors). There is a good deal of evidence which shows that during the period of low to moderate rates of inflation (absolute), real wages either stagnated or rose very little as compared with the general growth of profitability and incomes in the economy. Some studies have reported that they fell absolutely. ${ }^{25}$ Further, as we have noted already, nominal interest rates in the economy were kept at such low levels that even at these relatively moderate rates of inflation, the real return avail able to the suppliers of loanable funds was generally either negative or extremely low as compared with the rates of profit on physical investments financed by these funds. Thus we see that although the rate of inflation remaind relatively moderate over most of the period under consideration, the rise in prices was accompanied by a transfer of resources in favour of the capitalists as real wages and real interest rates stagnated. It may also be added that redistribution of income in favour of this class, especially the richer ones in this class, through this process was but one among several ways of doing so. This end was also pursued, directly or indirectly, through a host of other channels and government policies.

Another point that may be raised here is that to assess fully the effect of the income redistributive consequences of inflation, we should look at the whole of the private sector (including the corporate sector), nay, the whole of the economy so as to incorporate the composite effect on saving of redistribution of income both with in the private sector as well as from the private to the public sector. To see if the

${ }^{25}$ See, for example, Khan [19] 
substitution of total private sector saving or total national saving for total household saving as the dependent variable made any significant difference to the relationships estimated above, we re-estimated equation 4(a) over the same period after making the necessary substitutions. There was little change in the results as the coefficients of the rate of inflation remained negative and strongly significant. ${ }^{26}$ Indeed, this is what should be intuitively obvious in the case of Pakistan. If an economic variable exerts a strong and highly significant negative effect on saving in the household sector which accounts for about three-fourths of the total annual saving in the economy, it is difficult to imagine that its effect on saving in the economy as a whole can be positive.

We also ran some regressions using a quadratic relationship between the rate of saving and the rate of inflation, both at the sectoral and national levels. The rationale underlying this formulation is that whereas a relatively mild rate of inflation may promote saving, at higher rates the negative effects outweigh the positive effects so that saving is adversely affected. However, no useful results were obtained. Although the coefficients on the two price terms, i.e., $\frac{\Delta \mathrm{P}}{\mathrm{P}}$ and $\left(\frac{\Delta \mathrm{P}}{\mathrm{P}}\right)^{2}$, had the predicted signs, the positive coefficient (on $\frac{\Delta P}{P}$ ) was always statistically insignificant. As the results did not represent a significant improvement over the simple linear models considered above (as indicated by the F-test), they are not reported here.

\section{CONCLUSIONS}

The paper tested some household savings hypotheses with time-series data for Pakistan for the period 1950-51-1976-77. The permanent income model emphasising short-term adjustment lags between income and expenditure gave a much better explanation of the year-to-year changes in the sector's saving than did the simple Keynesian model based on current income only. The propensity to save out of transitory income was found to be much higher than that out of permanent income,

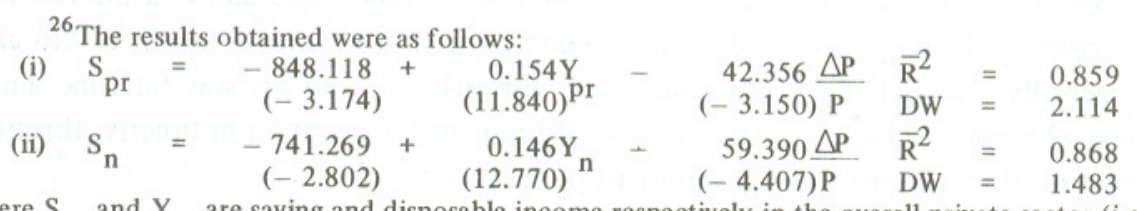
where $\mathrm{S}_{\mathrm{pr}}$ and $\mathrm{Y}_{\mathrm{pr}}$ are saving and disposable income respectively in the overall private sector (i.e. households plus corporate sector), and $\mathrm{S}_{\mathrm{n}}$ and $\mathrm{Y}_{\mathrm{n}}$ are national saving and national income
respectively (all in real terms). respectively (all in real terms)

In fact, the negative effect of inflation on saving increases in quantitątive terms when national saving is used as the dependent variable. Thus (ii) shows that now an increase in $\frac{\Delta P}{P}$ by one percentage point reduces saving by about 2.5 percent as compared with about 2 percent in the case of the comparable equation for the household sector (measured at the mean), suggesting that the transfer of resources from the private to public sector through the inflation tax tended to accentuate the adverse effect of inflation on saving. indicating that large and rapid increases in household income have a positive impact on the rate of saving. The rate of growth of income was also tried directly in the regressions and was found to be a highly significant determinant of the rate of saving in the sector. It appears that the sharp acceleration of income growth that took place during the early- and mid-1960s was a major factor behind the peak saving rates then recorded. The latter must in turn have helped to strengthen the former. By the same token, the slowing down of income growth towards the late 1960s and a further deceleration in the early 1970 s appear to have been important factors in causing the saving rates to fall appreciably from their earlier peak levels. This suggests a need to maintain the momentum of growth in the economy over a number of years so as to bring into play a sustained and mutually complementary relationship between savings and income growth.

The much better performance of the permanent income model than that of the simple current income hypothesis and the high significance of the rate of income growth as an influence on the propensity to save appear to be related closely to the structure of the Pakistan economy. Economic activity in the country is dominated by self-employed people, a very large proportion of whom are farmers. The incomes of this occupational category are subject to a relatively high degree of variability. In the case of farmers and other self-employed rural operatives, in addition, the consumption levels have a substantial traditionally determined component, which means that the overall level of consumption of this group responds relatively slowly to variations in income in the short run. These two factors together make for a relatively greater importance of variations in income as an influence on national saving behaviour. They give rise to relatively large savings out of transitory increments in income and, by the same token, relatively large reductions in savings in the case of transitory decrements in income.

The above is supported by some evidence available for countries with a broadly similar economic structure. For example, several studies of India have reported that the hypothesis of a positive differential between the propensities to save out of transitory and permanent components of income gives comparatively much better results for the rural sector. ${ }^{27}$ This could not be tested directly in this study because separate series on incomes and savings in the rural and urban sectors are not yet available in Pakistan. Some evidence is, however, available to the effect that a major factor behind the jump in saving rates in Pakistan in the early - and mid1960 s was a sharp acceleration in the growth of income in the agricultural sector after a period of near stagnation in the $1950 \mathrm{~s} .{ }^{28}$ This is consistent with the point made above and indicates that the pattern of income growth in this sector is of pivotal importance to the overall relationship between changes in income and saving

${ }^{27}$ See, for example, Choudhury [5] and Gupta [14]

${ }^{28}$ See Qureshi [26]. 
in the country. An implication of this is that the vicissitudes of weather that have long been a major determinant of year-to-year variations in agricultural output constitute an extremely important influence on the year-to-year behaviour of the national rate of saving.

An important finding of the paper is a strong positive correlation between the real return on financial assets and household saving. The real rate of interest on commonly held financial assets such as bank deposits was found to exercise a strong effect on household saving in financial assets. The evidence also indicated a significant complementary effect of financial asset accumulation on investment in real capital assets, a la McKinnon's hypothesis.

This finding contradicts the presumption underlying the low interest rate policy pursued in the country in the past that a rise in interest rates would have little effect on overall savings as all that would happend would be a portfolio adjustment in favour of interest-bearing assets. The conclusion to be drawn from our results is that by keeping real returns on commonly held financial assets depressed, this policy had a serious adverse effect on the propensity to save. Lower savings, in turn, had the effect of constraining investment, the very thing low interest rates were designed to promote.

The real rate of return on financial assets is an especially important influence on saving behaviour in the case of those groups in the population which, either because of resource constraints or because of vocation or tradition, do not normally invest directly in physical capital goods, e.g. wage-earners and the salaried middle class. This is particularly true of small savers among these groups, for whom practically the only means of earning some return on their modest savings is either to deposit them with commercial banks or to invest them in small postal savings deposits or certificates, both of which carry fixed nominal yields. In addition, the importance of financial assets such as commercial bank and postal deposits as instruments of saving in Pakistan, and hence of the real rate of return on these assets, has increased substantially over time with the spread of banking facilities. Increasing amounts of rural savings in excess of farmers' own investment requirements have taken the form of interest bearing deposits.

The evidence in favour of a complementary effect of financial asset accumulation (following an increase in the real rate of return on such assets) on investment in real capital assets appears to reflect the predominance in the country's economy of household entrepreneurs and small unincorporated business units with limited access to external finance for financing planned real investment. Since self-finance is the dominant means of financing investment for these entrepreneurs, an increase in the real rate of return on financial assets can stimulate both financial and real asset accumulation; higher financial savings enlarge the conduit of self-finance for later investment in real capital assets. Higher financial savings channelled through the financial system also serve to stimulate real investment where the latter was previously constrained by a lack of outside funds.
Inflation was found to have been strongly and negatively related to household saving. This was so despite the fact that the rate of inflation generally varied within a fairly moderate range of values. The explanation for this is to be found in the policy of keeping nominal interest rates low. At these low rates, which were adjusted upward only infrequently, even relatively moderate increases in inflation were enough almost completely to erode the modest nominal return available on financial savings. The adverse effect of inflation on household financial savings more than counterbalanced any positive effect it might have had through its income-redistributive effects.

The inference to be drawn from these reults is that financial policy should seek to ensure a reasonable real return to savers on their financial investments. To achieve this, it is necessary to follow a flexible interest rate policy, one that allows the nominal rates to adjust in line with the rate of inflation. Were interest payments to be abolished completely under the ongoing process of institutional change in the country and replaced by some form of profit sharing, the attractiveness to savers of the relevant financial instruments would then, of course, depend on the rates of profit earned on the investment of their proceeds and on the risk character of these investments.

\section{REFERENCES}

1. Abe, S., M. J. Fry, $\quad$ B. K. Min, P. Vongvipanond and T. P. Yu. "The Demand for Money in Pakistan: Some Alternative Estimates". Pakistan Development Review. Vol. XIV, No. 2. Summer 1975. pp. 249-257.

2. Abe, S., M. J. Fry, B. K. Min, P. Vongvipanond and T. P. Yu. "Financial Liberalisation and Saving in Economic Development: An Empirical Test for Six Countries". Pakistan Development Review. Vol. XVI, No. 3. Autumn 1977. pp. 298-308.

3. Akhtar, M. A. "The Demand for Money in Pakistan: Reply". Pakistan Development Review. Vol. XIV, No. 3. Autumn 1975. pp. 370-375.

4. Brown, G. T. Korean Pricing Policies and Economic Development in the 1960s. Baltimore: Johns Hopkins University Press. 1973.

5. Choudhury, U. M. R. "Income, Consumption and Saving in Urban and Rural India”. Review of Income and Wealth. Vol. 14. 1968. pp. 37-56.

6. Cooper, J. P. "Asymptotic Covariance Matrix of Procedures for Linear Regression in the Presence of First-Order Autoregressive Disturbances". Econometrica. Vol. 40, No. 2. March 1972. pp. 305-310.

7. Diwan, R, K. "The Effect of Prices on Savings". Economic Development and Cultural Change. Vol. 16, No. 3. April 1968. pp.430-435.

8. Duesenberry, J. Income, Saving and the Theory of Consumer Behaviour. Cambridge, Mass.: Harvard University Press. 1949. 
9. Farrel, M. J. "The New Theories of the Consumption Function". Economic Journal. Vol. LXIX. 1959. pp. 678-696.

10. Friedman, M. A Theory of the Consumption Function. Princeton: Princeton University Press. 1957.

11. Friend, I., and P. Taubman. "The Aggregate Propensity to Save: Some Concepts and Their Application to International Data". Review of Economics and Statistics. Vol. 48. 1966. pp. 113-23.

12. Fry, M. J. "Money and Capital or Financial Deepening in Economic Development". Journal of Money, Credit and Banking. Vol. 10, No. 4. November 1978. pp. $464-475$.

13. Gupta, K. L. "The Effect of Prices on Savings: Comment". Economic Development and Cultural Change. Vol. 20, No. 2. January 1972. pp. 330-337.

14. Gupta, K. L. "On Some Determinants of Rural and Urban Household Saving Behaviour”. Economic Record. Vol. 46. 1970. pp. 578-583.

15. Gupta, K. L. "Personal Saving in Developing Nations: Further Evidence". Economic Record. Vol. 46: 1970. pp. 243-9.

16. Houthakker, H. S. "On Some Determinants of Savings in Developed and Underdeveloped Countries”. In E.A.G. Robinson (Ed.), Problems in Economic Development. New York: Macmillan. 1965.

17. Houthakker, H. S., and L. D. Taylor. Consumer Demand in the United States: Analysis and Projections. Cambridge, Mass.: Harvard University Press. 1970 .

18. Johnston, J. Econometric Methods (2nd Ed.). New York: McGraw-Hill. 1972.

19. Khan, A. R. "What Has Been Happening to Real Wages in Pakistan", Pakistan Development Review. Vol. VII, No.3.Autumn 1967. pp.317-347.

20. Leff, N. H., and K. Sato. "A Simultaneous-Equation Model of Savings in Developing Countries”. Journal of Political Economy. Vol. 83, No. 6. December 1975. pp. 1217-1228.

21. Liviatan, N. "Consistent Estimation of Distributed Lags". International Economic Review. Vol.4. 1963.pp.44-52.

22. McKinnon, R. I. Money and Capital in Economic Development. Washington, D.C.: The Brookings Institution. 1973.

23. Mikesell, R.F., and J. E. Zinser. "The Nature of the Savings Function in Developing Countries: A Survey of the Theoretical and Empirical Literature". Journal of Economic Literature. Vol. 'XI, No. 1. March 1973. pp. 1-26.

24. Madigliani, F., and A. Ando. "The Life-Cycle Hypothesis of Saving: Aggregate Implications and Tests". American Economic Review. Vol. LIII, No. 1. March 1963. pp. 55-84.
25. Modigliani F., and R. Brumberg. "Utility Analysis and the Consumption Function: An Interpretation of Cross-Section Data”. In K. Kurihara (Ed.). Post-Keynesian Economics. New Brunswick: Rutgers University Press. 1954.

26. Qureshi, Z. M. "Saving in Pakistan, 1950-77: Estimation and Analysis". Unpublished Ph. D. Thesis, University of Oxford. 1980.

27. Ranis, G. Urban Consumer Expenditure and the Consumption Function. Karachi: Institute of Development Economics. 1961.

28. Singh, S. K. "The Determinants of Aggregate Savings". In S. K. Singh, Development Economics - Some Findings. Lexington, Mass.: Lexington Books. 1975.

29. Snyder, D. W. "Econometric Studies of Household Saving Behaviour in Developing Countries: A Survey”. Journal of Development Studies. Vol. 10, No. 1. October 1973.pp. 139-153.

30. Swamy, S. "A Dynamic Personal Savings Function and its Long-Run Implications". Review of Economics and Statistics. 50 (1968), 111-22.

31. Thirlwall, A. P. Inflation, Saving and Growth in Developing Economies. London, Macmillan, 1974.

32. Wallis, K.F. "Lagged Dependent Variables and Serially Correlated Errors: A Reappraisal of Three-Pass-Least-Squares". Review of Economics and Statistics. Vol. 49. 1967. pp. 555-67.

33. Weber, W. E. "The Effect of Interest Rates on Aggregate Consumption". American Economic Review. Vol. 60, No. 4. September 1970. pp. 591-600.

34. Williamson, J. G. "Income Growth and Savings". The Philippine Economic Journal. Vol. 8, No. 1.1969. pp. 54-74.

35. Williamson, J. G. "Personal Saving in Developing Nations: An Intra-temporal Cross-Section from Asia”. Economic Record. Vol. 44, No. 106. June 1968. pp. 194-210.

36. Wright, C. "Savings and the Rate of Interest". In A.C. Harberger and M. J. Bailey (Eds.). The Taxation of Income from Capital. Washington, D.C.: The Brookings Institution. 1969.

37. Wright, C. "Some Evidence on the Interest Elasticity of Consumption". American Economic Review. Vol. 57. 1967. pp. 850-5. 